\title{
West Nile Virus in Europe and Safety of Blood Transfusion
}

\author{
Giulio Pisani $^{a} \quad K$ aren Cristiano ${ }^{a}$ Simonetta Pupella $^{b} \quad$ Giancarlo Maria Liumbruno $^{b}$

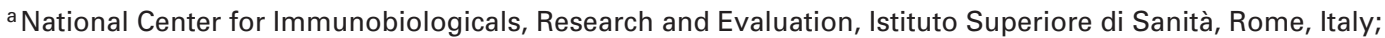 \\ ${ }^{b}$ National Blood Center, Istituto Superiore di Sanità, Rome, Italy
}

\section{Keywords}

NAT · Proficiency panel - Transfusion risks . Virus transmission. West Nile virus

\section{Summary}

West Nile virus (WNV) has become an increasing issue in the transfusion setting since 2002, when it was firstly shown in the USA that it can be transmitted through blood transfusion. Since then, several precautionary measures have been introduced in Europe in order to reduce the possible risk of transmission via transfusion/ solid organ transplantation. In addition, the epidemiological surveillance has been tightened and the network for communication of human WNV cases strengthened. This review will focus on WNV circulation and the safety of blood in Europe.

(c) 2016 S. Karger GmbH, Freiburg

\section{WNV Virology and Clinical Perspective}

West Nile virus (WNV) infection is a vector-borne disease caused by an enveloped ssRNA virus classified within the genus Flavivirus, family Flaviviridae, and phylogenetically and antigenically related to the Japanese encephalitis virus (JEV) [1]. The intensified surveillance for WNV infections in humans and animals resulted in the detection and isolation of many pathogenic isolates of $\mathrm{WNV}$, classified in at least seven different lineages [2, 3]. However, two major WNV lineages, lineage 1 (L1) and lineage 2 (L2), are responsible for the outbreaks observed in the past years. L1 is the most widespread and further segregates into different subclasses: WNV-1a (which includes strains from North, Central and South
America, Africa and the Middle East), WNV-1b (the Australian Kunjin) and WNV-1c (which includes some Indian strains) [4, 5]. L2 includes strains mainly present in sub-Saharan Africa and Madagascar and is traditionally associated with asymptomatic infections in humans. Several virulent L2 isolates were recently identified in other geographic areas such as Eastern Europe, where it has become endemic since its detection in Hungary (in 2004) [6], Austria (in 2008 and 2009) [7], Greece (in 2010) [8], and Italy (in 2011) [9]. An independent L2 strain, firstly detected in 2004 in Southern Russia, has been responsible for outbreaks of West Nile neuroinvasive disease (WNND) in Volvograd Oblast since 2007 and in Romania since 2010 [10-12]. Genetic studies demonstrated that all European L1 and L2 isolates derived from a limited number of independent introductions, most likely from Africa, followed by local spread and evolution [6].

During the enzootic transmission cycle, WNV circulates primarily between mosquitoes and wild birds. Although WNV has been isolated from over 40 species of mosquitoes, the principal mosquitoes involved in WNV transmission belong to the Culex genus, in particular to the Culex pipiens complex of species [13].

Many avian species in Europe are suitable reservoirs/amplifying hosts, producing high viral titers upon WNV infection. Infected mosquitoes also feed on blood of other vertebrate hosts and this leads to frequent infections in humans and horses. A vertical transmission of the virus, demonstrated by virus isolation from male mosquitoes as they do not take blood meals, followed by horizontal transmission can explain the maintenance of the infection cycle between mosquitoes and birds [14].

Human to human transmission of WNV infection has been documented through intrauterine exposure [15] and other transmission routes, i.e. breast feeding [16], blood transfusion [17], and organ transplantation [18].

The majority of WNV infections in humans are asymptomatic, while approximately $20 \%$ of infected individuals develop, after an

\section{KARGER}

Fax +497614520714

\section{(c) 2016 S. Karger GmbH, Freiburg}

$1660-3796 / 16 / 0433-0158 \$ 39.50 / 0$ 
incubation period of 3-14 days, a febrile self-limiting illness (West Nile fever, WNF) associated with headaches, myalgia, nausea, vomiting, and chills. In less than $1 \%$ of infected individuals, particularly the elderly or immunocompromised subjects [19], WNV infects neurons and causes a neuroinvasive disease with meningitis or encephalitis (WNND) and long-term sequelae like altered mental status, lethargy, cranial nerve palsies, acute flaccid paralysis, and movement disorders $[20,21]$. As these neurological symptoms are not specific only to WNV infections, laboratory tests are essential to confirm or exclude WNV infection. Because of short-term viremia and a low level of circulating virus as well as a late appearance of clinical signs when the viremic phase is over, the primary tools used to diagnose WNV infection consist of serological tests for specific IgM in serum or in cerebrospinal fluid (CSF) $[19,22]$. This class of antibodies is detectable one to several days after the onset of symptoms either by enzyme-linked immunosorbent assay or by hemagglutination inhibition methods. However, seropositivity has to be interpreted with care because of the frequent cross-reactivity with infection caused by other flaviviruses, as also reported by a recent external quality assessment (EQA) study on WNV serology [23]. IgM-positive samples should be systematically confirmed by a plaque reduction neutralization assay that is considered the gold standard diagnostic method for flavivirus serology [23]. This test is also adopted by the European Union (EU) case definition [24]. Moreover, IgM persistence can occur as these antibodies can sometimes be detected for months after infection [25]. Therefore, in areas where WNV circulation has occurred for more than a season, the sole detection of IgM could lead to a misdiagnosis of WNV infection as the symptoms could be due to another febrile illness. In these cases, IgG detection by an avidity assay can be useful to sort out recent from prior infections with persistent IgM. Though virus isolation is possible, cultures of blood, CSF, and tissues generally test negative in infected individuals due to the peculiar characteristics of WNV infection, i.e. brief duration of viremia (1-11 days) and low viral loads (often $<100 \mathrm{pfu} / \mathrm{ml}$ ). As detection of WNV RNA by nucleic acid amplification techniques (NAT) is quite sensitive in the early stage of infection, this is considered the elective method to check for the possible presence of viremia in blood and tissue/organ donors. As recently reported, WNV RNA can also be detected in urine of individuals with WNF or WNND up to 2 days from symptom onset or even longer and with a higher concentration than in blood or CSF $[26,27]$.

With respect to prevention, there is no human vaccine available at present. Considering the impact of WNV infection on the horse industry, only veterinary WNV vaccines are currently on the market: a formalin-inactivated WNV vaccine, a recombinant vaccine consisting of a Canarypox virus vector with insertion and expression of WNV membrane and envelope proteins, and a recombinant vaccine with WNV membrane and envelope proteins expressed in a yellow fever vector [28]

Currently, there are limited treatment options for patients infected with WNV. Only two classical antiviral compounds, interferon and ribavirin, have shown promising results in vitro, but it is unclear if these compounds are effective in patients [29]. Passive transferring of anti-WNV immunoglobulin was shown to be effective in mouse and hamster models and may be helpful in patients as demonstrated by several case reports, where improvement in humans with WNND after receiving immune $\gamma$-globulin was documented [30]. The use of humanized or human monoclonal antibodies or antibody fragments with therapeutic activity against WNV infection appears promising. Specific intravenous WNV immunoglobulin obtained from selected donors from WNV-endemic regions such as Israel could help to control the active infection of treated patients in terms of higher chances for survival or of diminished risks of immediate and/or long-term sequelae [31].

\section{The Emergence of WNV}

WNV was first isolated in 1937 from the blood of a woman suffering a febrile illness in the West Nile district of Uganda [32] and was associated with sporadic cases and outbreaks in Africa, the Middle East, and Asia [33]. Frequent outbreaks of severe WNND in humans and horses were subsequently reported in Europe and the Mediterranean Basin [34].

\section{Western Hemisphere}

Even if the first human WNV infection appeared in the USA as early as 1999 [35], the human epidemic did not increase dramatically until 2002. In this epidemic year, WNV was recognized in the USA as a virus that can be transmitted through blood transfusion with 23 confirmed cases of patients who acquired WNV through transfusion of red cells, platelets, or fresh frozen plasma $[17,36$, 37]. In the same year, WNV transmission was also reported following solid organ transplantation $[18,38]$. As a result of these findings and under the pressure of the Food and Drug Administration (FDA), the diagnostic kit manufacturers developed WNV NAT assays for blood screening that were broadly implemented under Investigational New Drug (IND) application in the summer of 2003: the Procleix WNV assay using the automated TIGRIS platform marketed by Novartis (now Grifols), which is based on transcription-mediated amplification technology developed by Gen-Probe (now Hologic), and the cobas TaqScreen WNV test running on the cobas s 201 system, a real-time RT-PCR developed by Roche. In the same year, Canadian blood centers also implemented NAT testing screening as a preventive measure by adopting the cobas TaqScreen WNV test.

In the USA, the WNV NAT testing program has been running all these years, relying on a combination of minipool testing (MP$\mathrm{NAT}$ ) and/or individual donation testing (ID-NAT). It has been remarkably successful, identifying 4,375 WNV-positive donations through the end of 2015: many of them are considered to be infectious (table 1). When a sample tested positive, the donor was temporarily deferred for 28 days (in Canada for 56 days). This 4 -week deferral period was established based on the viremic phase of a typical mosquito-borne WNV infection (1-11 days), thus provid- 
Table 1. Human cases of WNV infections ${ }^{1,2}$ reported in the USA

\begin{tabular}{lccc}
\hline Year & Number of human cases & Deaths & $\begin{array}{l}\text { Number of presumptive } \\
\text { viremic blood donors }\end{array}$ \\
\hline $1999-2002$ & 4,305 & 303 & NT \\
2003 & 9,862 & 264 & 818 \\
2004 & 2,539 & 100 & 224 \\
2005 & 3,000 & 119 & 417 \\
2006 & 4,269 & 177 & 361 \\
2007 & 3,630 & 124 & 326 \\
2008 & 1,356 & 44 & 174 \\
2009 & 720 & 32 & 109 \\
2010 & 1,021 & 57 & 117 \\
2011 & 712 & 43 & 137 \\
2012 & 5,674 & 286 & 597 \\
2013 & 2,469 & 119 & 420 \\
2014 & 2,205 & 97 & 344 \\
2015 & 1,996 & 111 & 331 \\
Total & 37,131 & 1,876 & 4,375 \\
\hline${ }^{1}$ Including neuroinvasive disease (such as meningitis or encephalitis) and non-neuroinvasive disease \\
(WN fever). \\
${ }^{2}$ Source: CDC, accessed on December 30, 2015. \\
\hline
\end{tabular}

ing reassurance that after this deferral period a specific humoral response would be detected and the virus cleared from the blood. However, in 2005, based on the data collected in the clinical trials showing that in rare instances an extended viremic period may occur in blood donors up to 104 days, a 120-day deferral for a NAT-positive donor was recommended by the FDA [38].

Because of automation constraints, the newly introduced WNV NAT tests were performed using minipools of either 6 (TaqScreen WNV test) or 16 (Procleix WNV assay) donations. Positive pools were resolved and tested again to identify the positive donation. Though the WNV NAT screening contributed to a decreased risk of transfusion transmission in the USA, the MP-NAT strategy reduced the assay sensitivity and increased the possibility of missing donors with very low viremia. In fact, studies carried out during the $2003 \mathrm{WNV}$ epidemic season identified at least 6 'MP-NAT breakthrough' WNV infections among blood recipients which were attributed to blood units with low levels of viremia that had escaped detection by MP-NAT involving 6 or 16 samples [39, 40]. Up to 2015 , more than 37,000 human infection cases were reported in the USA (table 1), while 5,308 were reported in Canada.

\section{Europe}

The first large outbreak in the EU of WNV occurred in Romania in 1996 with 352 WNND and 17 deaths [41]. In the subsequent years, the incidence of WNV in humans appeared to be quite low as only a few sporadic autochthonous cases were reported and only in defined geographical areas (Portugal, Spain, France, Italy, Czech Republic, Romania, and Hungary) [42]. Meanwhile, sporadic imported cases were reported in the Czech Republic, France, Germany, Denmark, the Netherlands, and Ireland [43] caused by traveling to areas with ongoing transmission of WNV to humans, such as Canada, Israel and mainly the USA, where an increasing number of autochthonous infections had been described since 1999. Therefore, the first WNV precautionary measure undertaken by the European Commission in 2004 was a 28-day deferral period for blood donors leaving areas with ongoing transmission of WNV (Directive 2004/33/EC (Annex III) [44] implementing Directive 2002/98/EC [45]). In 2007, WNV infection became a notifiable disease as per Commission Decision 2007/875/EC [46]. Furthermore, Commission Decision 2008/426/EC [47] established the criteria for case classification of human WNV infections (table 2) in order to allow comparability of the cases reported by member states to the Commission through the EU Early Warning and Response System and to allow their compilation by the European Centre for Disease Prevention and Control (ECDC) in a disease risk assessment report to be issued annually.

Since 2009, WNF in humans has become a notifiable disease at the EU level according to Commission Decision 2009/312/EC [48]. Thanks to this surveillance network, in 2010 a large outbreak of WNV infections with 262 human cases and 35 deaths that affected the northern part of Greece and Central Macedonia prompted the ECDC to alert the European countries again to intensify their WNV monitoring program. In the same year, autochthonous human cases of WNV were detected in Austria, Hungary, Italy, Romania, and Spain.

A regular monitoring of WNV infections in humans was initiated in 2011 by the ECDC, with weekly surveillance updates starting in June 2014. Table 3 reports the annual figures for both EU member states and surrounding countries from 2011 to 2015. The table reports all cases of WNV infections (both probable and confirmed) as per EU case definition (table 2). According to the ECDC map, 128 autochthonous WNV cases were detected in 2011 in the EU member states, the majority of which in Greece (100 cases) [49]. Moreover, Hungary, Italy, and Romania were involved in WNV cir- 
Table 2. Criteria for case classification of human WNV infections (Commission Decision 2008/426/ $\mathrm{EC})$.

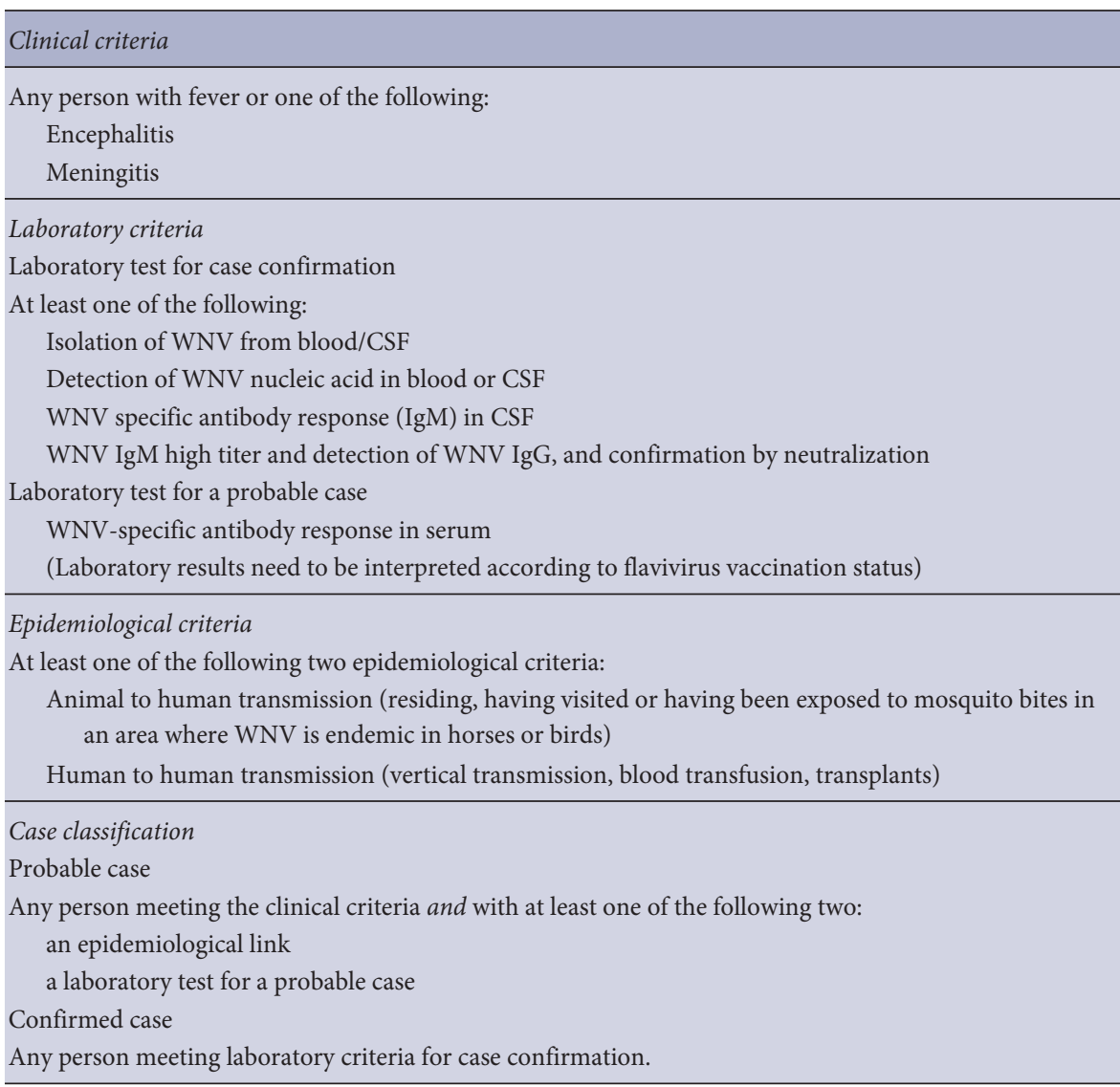

culation with human cases. In 2012, the number of autochthonous WNV cases in EU member states increased to 249, with 161 cases reported in Greece and 50 cases (WNND and WNF) reported in Italy. In addition to Hungary and Romania with 17 and 14 cases respectively, few WNV infections were reported also in Bulgaria and Croatia. The total number of EU autochthonous WNV cases in 2013 remained fairly constant (228). In Greece, a decrease of WNV cases (86) with respect to the 3 previous years was observed. On the contrary, a higher number of WNV cases was reported in Italy (69), Hungary (31), Romania (24), and Croatia (16). The number of EU autochthonous WNV cases drastically decreased to 74 in 2014 but slightly increased in 2015 (108). In particular, it is worth noting that only $15 \mathrm{WNV}$ cases were reported for Greece in 2014 and none in 2015. On the contrary, in 2015 Italy was the EU member state with the highest number of WNV cases: 38 WNND cases (19 in the Lombardy region, 17 in the Emilia Romagna region, 1 in the Veneto region, and 1 in the Piedmont region), $10 \mathrm{WNF}$ cases (2 in the Lombardy region and 8 in the Emilia Romagna region) and 16 blood donors that tested WNV-RNA-positive by NAT (10 in the Lombardy region and 6 in the Emilia Romagna region).

From an epidemiological point of view, annual late-summer outbreaks of WNV can be considered as a regular occurrence in some EU countries, and, in particular, can be considered endemic in some regions of the Mediterranean Basin, with the exception of Greece for the year 2015. The reoccurrence of WNV infections in the same places over the years could be a sign of the endemic nature of the disease rather than of a new introduction of the virus. In fact, mosquitoes may acquire the infection by vertical transmission between generations via the egg stage. However, one cannot exclude that the implementation of a surveillance system could also have contributed to highlight the above-mentioned reoccurrence.

\section{Safety of Blood at the European Level}

European Directive 2004/33/EC requires that travelers from an area (administrative district) with ongoing transmission of WNV in humans are deferred for 28 days. Following this directive, EU countries decide every year, on the basis of the epidemiological situation in Europe, in the Mediterranean Basin and in other countries with ongoing transmission of WNV to humans (e.g. North America and Mexico), to exclude donors from blood donation after their return from the above-mentioned countries [50]. However, as ongoing transmission of WNV in humans generally occurs during several months over the summer, it coincides with an increase in traveling. Therefore, in order to avoid shortage of blood and blood components, some EU transfusion centers have decided to apply the option offered by the above-mentioned directive, i.e. to carry out WNV NAT testing in place of deferral. For instance, some German transfusion centers implemented WNV NAT in the summer of 2014 and 2015. To comply with the minimum analytical sensitivity of 250 copies/ml of WNV RNA required by the Paul Ehrlich Institute, the NAT testing was carried out on minipools of 8-10 donations [51]. 
Table 3. Human cases of WNV infections ${ }^{1,2}$ reported in European Member States and neighboring countries between 2011 and 2015

\begin{tabular}{|c|c|c|c|c|c|}
\hline \multirow[t]{2}{*}{ Country } & \multicolumn{5}{|c|}{ Number of human cases } \\
\hline & 2011 & 2012 & 2013 & 2014 & 2015 \\
\hline Austria & - & - & - & 1 & 7 \\
\hline Bulgaria & - & 2 & - & - & 2 \\
\hline Croatia & - & 5 & 16 & - & - \\
\hline Czech Republic & - & - & 1 & - & - \\
\hline France & - & - & - & - & 1 \\
\hline Greece & 100 & 161 & 86 & 15 & - \\
\hline Hungary & 3 & 17 & 31 & 11 & 18 \\
\hline Italy & 14 & 50 & 69 & 24 & $61^{3}$ \\
\hline Portugal & - & - & - & - & 1 \\
\hline Romania & 11 & 14 & 24 & 23 & 19 \\
\hline Slovenia & - & - & 1 & - & - \\
\hline Total EU MS & 128 & 249 & 228 & 74 & 109 \\
\hline Albania & 2 & - & - & - & - \\
\hline Algeria & - & 1 & - & - & - \\
\hline Bosnia/Herzegovina & - & - & 3 & 13 & - \\
\hline Israel & 39 & 83 & 63 & 17 & 125 \\
\hline Kosovo & - & 4 & - & - & - \\
\hline Macedonia & 4 & 6 & 1 & - & - \\
\hline Montenegro & - & 1 & 4 & - & - \\
\hline Occupied Palestinian Territory & - & 2 & - & 1 & 1 \\
\hline Russian Federation & 153 & 447 & 177 & 29 & 39 \\
\hline Serbia & - & 69 & 302 & 76 & 28 \\
\hline Turkey & 3 & - & - & - & - \\
\hline Tunisia & 3 & 63 & 6 & - & - \\
\hline Ukraine & 8 & 12 & 1 & - & - \\
\hline Total neighboring countries & 212 & 688 & 557 & 136 & 193 \\
\hline $\begin{array}{l}{ }^{1} \text { Including neuroinvasive disea } \\
\text { (WN fever). } \\
{ }^{2} \text { Source: ECDC, accessed on } 30 \\
{ }^{3} \text { To the author's knowledge, th } \\
\text { number as they were not timel }\end{array}$ & \multicolumn{4}{|c|}{$\begin{array}{l}{ }^{1} \text { Including neuroinvasive disease (such as meningitis or encephalitis) and non-neuroinvasive disease } \\
\text { (WN fever). }\end{array}$} & $\begin{array}{l}\text { isease } \\
\text { o this } \\
\text { ies. }\end{array}$ \\
\hline
\end{tabular}

\section{Blood Screening by NAT}

The first two NAT assays available on the market for WNV blood screening were able to detect both WNV L1 and L2: Roche cobas TaqScreen WNV Test (Roche Molecular Systems, Branchburg, NJ, USA) on cobas s 201 System (Roche Instrument Center, Rotkreuz, Switzerland) and the Procleix WNV assay on Procleix Tigris System (Novartis Diagnostics, now Grifols, Frankfurt/M., Germany) [52, 53]. Both assays received FDA licensure for MPNAT ( 6 and 16 donations, respectively) or ID-NAT as well as for screening of organ and tissue donors (in ID format).

With respect to WNV L1, both assays were validated for their analytical sensitivity by their respective manufacturers using a dilution series of a WNV L1 secondary standard calibrated against the Health Canada Service reference preparation (HC-SC WNV Nat Ref 001/03) [54]. The analytical sensitivity, expressed as $95 \%$ limit of detection (LOD), proved to be about 40 copies $/ \mathrm{ml}$ for cobas TaqScreen WNV and about 10 copies/ml for Procleix WNV (as reported in the respective packaging inserts).
Regarding WNV L2, both test kit manufacturers used the same WNV RNA Qualification Panel QWN701 (BBI Diagnostics, Cardiff, UK) to validate the analytical sensitivity. A different 95\% LOD was estimated: about 5 copies/ml for cobas TaqScreen WNV and about 20 copies/ml for Procleix WNV) [52, 53].

Both manufacturers are now on the market with a new WNV test kit adapted for their new platforms.

In 2014 Roche launched the cobas WNV test for use on the cobas $6800 / 8800$ System. The new test shows increased sensitivity for both lineages expressed as 95\% LOD: about 12.9 copies $/ \mathrm{ml}$ for WNV L1 and 6.2 copies/ml for WNV L2.

In the same year Grifols launched the Procleix WNV assay for Procleix Panther System. The sensitivity of this assay for both lineages, expressed as $95 \% \mathrm{LOD}$, is 12 copies $/ \mathrm{ml}$, therefore, similar to the that of the previous kit for WNV L1, while significantly improved for WNV L2.

The above-mentioned NAT assays show also a broad cross-reactivity to other flaviviruses. In particular, both versions of cobas TaqScreen WNV kits are able to detect Kunjin virus (KUNV), JEV, 
Table 4. List of WNV Reference Preparations currently available from EU public health institutions

\begin{tabular}{|c|c|c|c|c|c|}
\hline Virus/lineage & Batch & $\begin{array}{l}\text { Concentration, } \\
\text { copies } / \mathrm{ml}\end{array}$ & Supplier & Traceable to & Notes \\
\hline WNV L1 & $9002 / 14$ & 140,000 & PEI & HC SC $001 / 03$ & $\begin{array}{l}\text { lyophilized preparation } \\
\text { New York isolate } 1999\end{array}$ \\
\hline WNV L1 & ISS-0213 & 1,500 & ISS & HC SC $001 / 03$ & $\begin{array}{l}\text { liquid preparation } \\
\text { New York isolate } 1999\end{array}$ \\
\hline WNV L1 & ISS- 0410 & 150,000 & ISS & ISS- 0213 & $\begin{array}{l}\text { liquid preparation } \\
\text { Italian strain }\end{array}$ \\
\hline WNV L2 & ISS- 0513 & $12,600,000$ & ISS & ISS- 0213 & $\begin{array}{l}\text { liquid preparation } \\
\text { Greek strain }\end{array}$ \\
\hline
\end{tabular}

Murray Valley encephalitis virus, and Saint Louis encephalitis virus. With respect to Procleix WNV, false-positive results only to KUNV, but not to other flaviviruses from the JEV serogroup, were described.

Other NAT assays are currently used in Germany for WNV screening: the DRK WNV PCR kit (DRK), the RealStar WNV RTPCR Kit 1.0 (Altona Diagnostics, Hamburg, Germany) and the WNV PCR Kit (GFE Blut, Frankfurt/M., Germany). The 95\% LOD for WNV L1 and L2 of these assays is about 20 copies/ml (personal communication from the manufacturer), 30 copies $/ \mathrm{ml}$, and $15 \mathrm{cop}$ ies/ml, respectively. Recently, two additional WNV NAT in-house assays were evaluated by a German transfusion center for their capability to detect WNV L1 and L2 [51].

\section{Reference Material for WNV NAT Assays}

Over the years, the establishment of World Health Organization (WHO) International Standards (ISs) for blood-borne viruses (e.g. $\mathrm{HCV}$ ) and the adoption of International Units (IU) have provided kit manufacturers and testing laboratories with an appropriate preparation to validate their NAT assays for blood screening [54]. In particular, the WHO ISs have enabled the comparison of the analytical sensitivity of different NAT assays by means of their $95 \%$ LOD. In addition, ISs have been used to calibrate secondary reference materials.

With respect to WNV, no WHO IS for WNV RNA is available at present. A reference preparation, having a titer expressed in copies/ml, was obtained in 2003 from a WNV L1 isolated during the epidemic season in New York. This material (HC-SC WNV Nat Ref 001/03) was established through a collaborative study organized by the Health Canada Service. [55]. The preparation, which is no longer available, was largely used by laboratories to validate their in-house NAT assays and by kit manufacturers. Moreover, it was employed for the calibration of WNV-positive controls available on the market or for the calibration of reference materials (table 4). In particular, in 2013 the Istituto Superiore di Sanità (ISS) calibrated, through an international collaborative study, three reference materials (one represented by WNV L1 and two by WNV L2) using a secondary preparation calibrated against the HC-SC WNV (G. Pisani, personal communication).

West Nile Virus in Europe and Safety of Blood Transfusion

\section{MP-NAT versus ID-NAT}

At present, the introduction of WNV NAT testing of blood donations represents the most effective strategy to prevent WNV transmission via blood transfusion. However, whether to use MPNAT or ID-NAT is still being debated. In fact, WNV transmission was shown to occur with very low levels of RNA that had apparently escaped detection by MP-NAT. In the period 2003-2014, a total of 13 'MP-NAT breakthrough' infections attributed to transmission by blood transfusion after the implementation of WNV NAT screening were reported in the USA [56]. The viral load of 1,508 confirmed positive donations collected by the American Red Cross from 2003 to 2012 ranged from 5 to a maximum of 720,000 copies/ml. Of these, 535 donations (35.4\%) were identifiable only by ID-NAT with a mean titer of 88 copies $/ \mathrm{ml}$. This finding was confirmed by the data obtained in Italy during the 2013 WNV epidemic season when 16/19 WNV-RNA confirmed positive donations were investigated in order to determine their viral load. The mean plasma viral load was found to be about $2.3 \times 10^{3}$ copies $/ \mathrm{ml}$ (SD $3.3 \times 10^{3}$ copies $/ \mathrm{ml}$; range, 50-2.0 $\times 10^{4}$ copies $/ \mathrm{ml}$ ) [57]. In particular, 6 of these 16 positive samples had a WNV level below 100 copies/ml ( 3 of them were negative for both IgM/IgG, 2 were positive only for $\operatorname{IgG}$, and 1 was positive for both $\operatorname{IgM} / \operatorname{IgG}$ ).

Though a zero risk cannot be guaranteed in a transfusion setting, these data strongly point to the need to perform ID-NAT in WNV-affected areas in order to increase the sensitivity of the assay and avoid missing any low-level viremic donations. In this respect, it should be noticed that Commission Directive 2014/110/EU, amending Directive 2004/33/EC, specifies that WNV NAT should be carried out on individual donations [58].

\section{EQA Studies for Laboratories Performing WNV NAT for Blood Screening}

Participation in EQA studies is recognized as an important factor in quality assurance, as laid down in Directive 2005/62/EC [59]. Therefore, testing laboratories should verify the quality of their techniques through ongoing participation in EQA studies. Based on this consideration, the Italian National Blood Center (NBC) and the National Center for Immunobiological Research and Evaluation (CRIVIB) of the ISS have organized on an annual 
Table 5. NAT assays used in the 2015 EQA study for WNV

\begin{tabular}{|c|c|c|c|c|c|}
\hline Code & Commercial kit & Instrument & Manufacturer & $\begin{array}{l}95 \% \mathrm{LOD}, \\
\text { copies } / \mathrm{ml}\end{array}$ & $\begin{array}{l}\text { Number of } \\
\text { participants }\end{array}$ \\
\hline A & $\begin{array}{l}\text { cobas TaqScreen West } \\
\text { Nile Virus kit }\end{array}$ & cobas s 201 system & Roche & $\begin{array}{l}\text { WNV L1: } 40 \\
\text { WNV L2: } 5\end{array}$ & 9 \\
\hline B & cobas WNV kit & $\begin{array}{l}\text { cobas } 6800 / 8800 \\
\text { system }\end{array}$ & Roche & $\begin{array}{l}\text { WNV L1: } 16.9 \\
\text { WNV L2: } 6.2\end{array}$ & 4 \\
\hline C & Procleix WNV Assay & Panther system & Grifols & $\begin{array}{l}\text { WNV L1: } 12 \\
\text { WNV L2: } 12\end{array}$ & 8 \\
\hline D & Procleix WNV & Tigris System & Grifols & $\begin{array}{l}\text { WNV L1: } 10 \\
\text { WNV L2: } 20\end{array}$ & 6 \\
\hline E & WNV PCR kit & Not reported & GFE Blut mbH & $\begin{array}{l}\text { WNV L1: } 15.4 \\
\text { WNV L2: } 15.4\end{array}$ & 1 \\
\hline
\end{tabular}

Table 6. Results of the 2015 EQA study for $\mathrm{WNV}^{\mathrm{a}}$

\begin{tabular}{lclllll}
\hline Virus & Copies/ml & \multicolumn{2}{l}{ NAT assay } & & \\
\cline { 3 - 6 } & & $\mathrm{A}$ & $\mathrm{B}$ & $\mathrm{C}$ & $\mathrm{D}$ & $\mathrm{E}$ \\
\hline WNV L1 & 316 & $18 / 18(100 \%)$ & $8 / 8(100 \%)$ & $16 / 16(100 \%)$ & $12 / 12(100 \%)$ & $2 / 2(100 \%)$ \\
& 100 & $18 / 18(100 \%)$ & $8 / 8(100 \%)$ & $16 / 16(100 \%)$ & $12 / 12(100 \%)$ & $2 / 2(100 \%)$ \\
& 31 & $16 / 18(88.9 \%)$ & $8 / 8(100 \%)$ & $16 / 16(100 \%)$ & $12 / 12(100 \%)$ & $2 / 2(100 \%)$ \\
& 10 & $9 / 18(50 \%)$ & $6 / 8(75 \%)$ & $16 / 16(100 \%)$ & $9 / 12(75 \%)$ & $2 / 2(100 \%)$ \\
\hline WNV L2 & 10,000 & $18 / 18(100 \%)$ & $8 / 8(100 \%)$ & $16 / 16(100 \%)$ & $12 / 12(100 \%)$ & $2 / 2(100 \%)$ \\
& 1,000 & $18 / 18(100 \%)$ & $8 / 8(100 \%)$ & $16 / 16(100 \%)$ & $12 / 12(100 \%)$ & $2 / 2(100 \%)$ \\
& 100 & $17 / 17(100 \%)$ & $8 / 8(100 \%)$ & $16 / 16(100 \%)$ & $12 / 12(100 \%)$ & $2 / 2(100 \%)$ \\
& 10 & $7 / 18(38.9 \%)$ & $8 / 8(100 \%)$ & $13 / 16(81 \%)$ & $8 / 12(67 \%)$ & $2 / 2(100 \%)$ \\
\hline
\end{tabular}

basis since 2010 an EQA study for Italian blood transfusion centers (BTCs) performing WNV NAT testing of blood donations $[60,61]$.

In the last NAT EQA study for WNV carried out in 2015, both WNV L1 and WNV L2 were used to prepare the positive samples of the panels. The inclusion of WNV L2 is an appropriate choice considering that this lineage has been circulating for several years in Italy as well as in other European countries. In this study, a total of 28 laboratories (not only from Italy but also from Germany and Ireland) participated with five different NAT assays (table 5). The 316 and the 100 copies/ml samples of WNV L1 were correctly detected as positive in $100 \%$ of the cases by all NAT assays. With respect to the samples containing less than 100 copies $/ \mathrm{ml}$, the results were as expected, i.e. in line with the 95\% LOD stated by the test kit manufacturers for L1 (table 6). Regarding WNV L2, the 10,000, 1,000 and 100 copies/ml samples were correctly detected as positive in $100 \%$ of the cases by all NAT assays. Also for this lineage, detection of the 10 copies/ml samples appears to fit in with the respective 95\% LOD of the test kits used (table 3). The improved sensitivity for WNV RNA of the new kit using cobas $6800 / 8800$ with respect to the previous kit using cobas s 201 is confirmed in this EQA study.

Overall, the 2015 EQA study for WNV achieved its predefined objective, i.e., to provide participants with a valid tool to assess the quality of their analytical performance and the competence of their operators.

\section{Impact on Blood Safety of the Preventive Measures Adopted in Italy}

From 2009 to 2014, the NBC implemented, as a preventive measure, WNV NAT testing of all donations (peripheral blood, bone marrow and cord blood stem cell donations) generally from July to November [62]. This measure was implemented in all those areas (provinces) where the evidence of viral circulation was obtained from animal and vector WNV surveillance. Furthermore, the NBC adopted the definition of 'affected area' as an area where a human case of WNND and/or a WNV-NAT-positive donor had been confirmed. In the event of an area falling within this definition, the NBC would enforce a nationwide 28-day deferral for blood donors who had spent at least one night in these areas.

For the 2015 season, general and specific measures were adopted to prevent transfusion-transmitted WNV infection. In particular, an active integrated entomologic and veterinary WNV surveillance was implemented on May 15, 2015 in the Piedmont, Lombardy, Friuli Venezia Giulia, Veneto, and Emilia-Romagna regions, which were concerned by WNV circulation in previous years. This surveillance was based on a shared plan aiming to guarantee standardized surveillance of viral circulation [63, 64]. The remaining regions adopted the national veterinary surveillance plan enacted by the Ministry of Health with the decree of November 27, 2007. Moreover, active surveillance of WNND in humans 
Table 7. WNV NAT screening in Italy

\begin{tabular}{lll}
\hline Year & $\begin{array}{l}\text { Number of donations tested } \\
\text { by WNV NAT }\end{array}$ & $\begin{array}{l}\text { Number of positive } \\
\text { donations }\end{array}$ \\
\hline 2009 & 59,815 & 2 \\
2010 & 118,295 & 6 \\
2011 & 119,345 & 4 \\
2012 & 116,255 & 14 \\
2013 & 284,564 & 19 \\
2014 & 324,511 & 4 \\
2015 & $300,000^{1}$ & 16 \\
\hline${ }^{1}$ Updated as of November 2015, not to be considered definitive. \\
\hline
\end{tabular}

was systematically in place nationwide/year-round, according to the provisions annually issued by the Ministry of Health for surveillance of Arbovirosis. Trigger criteria for the implementation of WNV NAT testing for screening of blood donors from June to October 2015 were: i) notification of WNV circulation through entomological (vector mosquitoes) and veterinary surveillance (wild birds) in the regions where the integrated surveillance plan was in place and/or ii) notification of WNV human cases (WNND or WNF). In both cases, WNV NAT testing was timely introduced in the concerned provinces and was performed by ID-NAT. WNV NAT screening continued until the end of the surveillance season, i.e. November 2015. Nationwide, all donors having spent at least one night in the Italian provinces where WNV NAT testing was introduced as a consequence of the trigger criteria reported above were deferred for 28 days. Alternatively, in order to avoid critical blood shortages, donors were admitted to donate provided their donations were tested by WNV ID-NAT. The same was adopted for donors coming from the USA, Canada, and any other EU or non-EU countries where WNV human cases were reported by the ECDC. As in the past, a constant and efficient communication and cooperation among all involved institutional healthcare bodies (regional public health services, National Institute of Health, National Veterinary Reference Center for WNV, Ministry of Health, regional blood centers, NBC) contributed to immediately localize WNV circulation and adopt preventive actions.
The seasonal preventive measures for WNV implemented in Italy between 2009 and 2015 in the affected areas appear to have effectively improved the safety of the blood supply as no cases of transfusion-transmitted WNV infection have been reported by the national hemovigilance system or by the National Center for Epidemiology, Surveillance and Health Promotion. It should be noted that in this period, out of a total of more than 1,000,000 blood donations tested for WNV RNA, 65 viremic donations were detected (table 7). Considering that most positive donations were whole blood donations and that each of these is systematically fractionated into three different blood components (red cells, buffy coat/ platelets, and plasma), a considerable number of blood recipients were spared exposure to these potentially infectious units. As a high proportion of blood recipients are immunocompromised and many of them are subject to chronic or intensive transfusion treatments, they are at higher risk of contracting symptomatic WNV infection. Furthermore, once they become infected, they are more prone to develop WNND, thus becoming a heavy burden on the public health system.

\section{Conclusion}

Based on the widespread outbreaks occurring in the last two decades, WNV can no longer be considered a minor risk for humans but rather a global threat. In the transfusion setting, the preventive measures implemented so far, i.e. the 28-day deferral and the WNV NAT, have proved to be able to control the risk of WNV infection as there is no record of transmission of WNV through blood transfusion. With this intention, a great contribution has been made by a more capillary epidemiological surveillance and by an enhanced cooperation among the interested parties. This approach has undoubtedly paved the way to face other vector-borne global emergencies.

\section{Disclosure Statement}

The authors declared no conflict of interest.

\section{References}

1 Colpitts TM, Conway MJ, Montgomery RR, Fikrig E: West Nile virus: biology, transmission, and human infection. Clin Microbiol Rev 2012;25:635-648.

2 Pauli G, Bauerfeind U, Blumel J, Burger R, Drosten C, Groner A, Gurtler L, Heiden M, Hildebrandt M, Jansen B, Montag-Lessing T, Offergeld R, Seitz R, Schlenkrich U, Schottstedt V, Strobel J, Willkommen H: West Nile virus. Transfus Med Hemother 2013;40:265-284.

$\checkmark 3$ Rizzoli A, Jimenez-Clavero MA, Barzon L, Cordioli P, Figuerola J, Koraka P, Martina B, Moreno A, Nowotny N, Pardigon N, Sanders N, Ulbert S, Tenorio A: The challenge of West Nile virus in Europe: knowledge gaps and research priorities. Euro Surveill 2015;20:pii: 21135.

4 Bondre VP, Jadi RS, Mishra AC, Yergolkar PN Arankalle VA: West Nile virus isolates from India: evidence for a distinct genetic lineage. J Gen Virol 2007; $88: 875-884$.
5 Blitvich BJ: Transmission dynamics and changing epidemiology of West Nile virus. Anim Health Res Rev 2008;9:71-86.

6 Bakonyi T, Ivanics E, Erdely K, Ursu K, Ferenczi E, Weissenbock H, Nowotny N: Lineage 1 and 2 strains of encephalitic West Nile virus, central Europe. Emerg Infect Dis 2006;12:618-623.

7 Wodak E, Richter S, Bagó Z, Revilla-Fernandez S, Weissenbock H, Nowotny N, Winter P: Detection and molecular analysis of West Nile virus infections in birds of prey in the eastern part of Austria in 2008 and 2009. Vet Microbiol 2011;149:358-366

8 Papa A, Bakonyi T, Xanthopoulou K, Vasquez A, Tenorio A, Nowotny N: Genetic characterization of West Nile virus lineage 2 Greece, 2010. Emerg Infect Dis 2011;17:920-922.
9 Bagnarelli P, Marinelli K, Trotta D, Monachetti A, Tavio M, Del Gobbo R, Capobianchi MR, Menzo S, Nicoletti L, Magurano F, Varaldo PE: Human case of autochthonous West Nile virus lineage 2 infection in Italy, September 2011. Euro Surveill 2011;16:pii: 20002.

10 Platonov AE, Karan LS, Shopenskaia TA, Fedorova MV, Koliasnikova NM, Rusakova NM, Shishkina LV, Arshba TE, Zhuravlev VI, Govorukhina MV, Valentseva AA, Shipulin GA: Genotyping of West Nile fever virus strains circulating in southern Russia as an epidemiological investigation method: principles and results (in Russian). Zh Mikrobiol Epidemiol Immunobiol 2011;2:29-37. 
-11 Sirbu A, Ceianu CS, Panculescu-Gatej RI, Vazquez A, Tenorio A, Rebreanu R, Niedrig M, Nicolescu G, Pistol A: Outbreak of West Nile virus infection in humans, Romania, July to October 2010. Euro Surveill 2011; 16:pii:19762.

12 Kolodziejek J, Marinov M, Kiss BJ, Alexe V, Nowotny $\mathrm{N}$ : The complete sequence of a West Nile virus lineage 2 strain detected in a Hyalomma marginatum marginatum tick collected from a song thrush (Turdus philomelos) in eastern Romania in 2013 revealed closest genetic relationship to strain Volgograd 2007. PLoS One 2014;9:e109905.

13 Fonseca DM, Keyghobadi N, Malcolm CA, Mehmet C, Schaffner F, Mogi M, Fleischer RC, Wilkerson RC: Emerging vectors in the Culex pipiens complex. Science 2004;303:1535-1538.

14 Anderson JF, Main AJ: Importance of vertical and horizontal transmission of West Nile virus by Culex pipiens in the Northeastern United States. J Infect Dis 2006;194:1577-1579.

15 Centers for Disease Control and Prevention (CDC): Intrauterine West Nile virus infection - New York, 2002. MMWR Morb Mortal Wkly Rep 2002;51:1135-1136.

16 Centers for Disease Control and Prevention (CDC): Possible West Nile virus transmission to an infant through breast-feeding - Michigan, 2002. MMWR Morb Mortal Wkly Rep 2002;51:877-878.

17 Pealer LN, Marfin AA, Petersen LR, Lanciotti RS, Page PL, Stramer SL, Stobierski MG, Signs K, Newman B, Kapoor H, Goodman JL, Chamberland ME; West Nile Virus Transmission Investigation Team: Transmission of West Nile virus through blood transfusion in the United States in 2002. N Engl J Med 2003;349:12361245.

18 Iwamoto M, Jernigan DB, Guasch A, Trepka MJ, Blackmore CG, Hellinger WC, Pham SM, Zaki S, Lanciotti RS, Lance-Parker SE, DiazGranados CA, Winquist AG, Perlino CA, Wiersma S, Hillyer KL, Goodman JL, Marfin AA, Chamberland ME, Petersen LR; West Nile Virus in Transplant Recipients Investigation Team: Transmission of West Nile virus from an organ donor to four transplant recipients. N Engl J Med 2003;348:2196-2203.

19 Sampathkumar P: West Nile virus: epidemiology, clinical presentation, diagnosis and prevention. Mayo Clin Proc 2003;78:1137-1144.

20 Sejvar JJ: The long-term outcomes of human West Nile virus infection. Clin Infect Dis 2007;44:1617-1624.

-21 Loeb M, Hanna S, Nicolle L, Eyles J, Elliott S, Rathbone M, Drebot M, Neupane B, Fearon M, Mahony J: Prognosis after West Nile virus infection. Ann Intern Med 2008;149:232-241.

22 Niedrig M, Sonnenberg K, Steinhagen K, Paweska JT: Comparison of ELISA and immunoassays for measurement of IgG and IgM antibody to West Nile virus in human sera against virus neutralization. J Virol Methods 2007;139:103-105.

-23 Sanchini A, Donoso-Mantke O, Papa A, Sambri V, Teichmann A, Niedrig M: Second international diagnostic accuracy study for the serological detection of West Nile virus infection. PLoS Negl Trop Dis 2013; 7:e2184.

24 European Commission: Commission implementing decision of August 8, 2012 amending Decision 2002/253/EC laying down case definitions for reporting communicable diseases to the Community network under Decision No 2119/98/EC of the European Parliament and of the Council. Official Journal of the European Union. Luxembourg: Publications Office of the European Union. 27.9.2012: L 262:1-57.

25 Prince HE, Tobler LH, Yeh C, Gefter N, Custer B, Busch MP: Persistence of West Nile virus-specific antibodies in viremic blood donors. Clin Vaccine Immunol 2007;14:1226-1230.
26 Barzon L, Pacenti M, Franchin E, Pagni S, Martello T, Cattai M, Cusinato R, Palù G: Excretion of West Nile virus in urine during acute infection. J Infect Dis 2013; 208:1086-1092.

27 Barzon L, Pacenti M, Franchin E, Squarzon L, Sinigaglia A, Ulbert S, Cusinato R, Palù G: Isolation of West Nile virus from urine samples of patients with acute infection. J Clin Microbiol 2014;52:3411-3413.

28 Seino KK, Long MT, Gibbs ET, Bowen RA, Beachboard SE, Humphrey PP, Dixon MA, Bourgeois MA: Comparative efficacies of three commercially available vaccines against West Nile virus (WNV) in a short-duration challenge trial involving an equine WNV encephalitis model. Clin Vaccine Immunol 2007; 14:1465-1471.

29 Anderson J, Rahal JJ: Efficacy of interferon alpha-2b and ribavirin against West Nile virus in vitro. Emerg Infect Dis 2002;8:107-108.

30 Diamond MS: Progress on the development of therapeutics against West Nile virus. Antiviral Res 2009;83: 214-227.

31 Ben-Nathan D, Gershoni-Yahalom O, Samina I, Khinich Y, Nur I, Laub O, Gottreich A, Simanov M, Porgador A, Rager-Zisman B, Orr N: Using high titer West Nile intravenous immunoglobulin from selected Israeli donors for treatment of West Nile virus infection. BMC Infect Dis 2009;17:9-18

32 Smithburn KC, Hughes TP, Burke AW, Paul JH: A neurotropic virus isolated from the blood of a native of Uganda. Am J Trop Med Hyg 1940;20:471-492.

33 Murgue B, Zeller H, Duebel V: The ecology and epidemiology of West Nile virus in Africa, Europe and Asia; in Mackenzie JS, Barrett AD, Deubel V (eds): Japanese Encephalitis and West Nile Viruses. New York, Springer, 2002, pp 195-221

34 Calistri P, Giovannini A, Hubalek Z, Ionescu A, Monaco F, Savini G, Lelli R: Epidemiology of West Nile in Europe and in the Mediterranean Basin. Open Virol J 2010;4:29-37.

35 Lanciotti RS, Roehrig JT, Deubel V, Smith J, Parker M, Steele K, Crise B, Volpe KE, Crabtree MB, Scherret JH, Hall RA, MacKenzie JS, Cropp CB, Panigrahy B, Ostlund E, Schmitt B, Malkinson M, Banet C, Weissman J, Komar N, Savage HM, Stone W, McNamara T, Gubler DJ: Origin of the West Nile virus responsible for an outbreak of encephalitis in the northeastern United States. Science 1999;286:2333-2337.

36 Biggerstaff BJ, Petersen LR: Estimated risk of West Nile virus transmission through blood transfusion during an epidemic in Queens, New York City. Transfusion 2002;42:1019-1026.

37 Centers for Disease Control and Prevention (CDC): Update: West Nile virus screening of blood donations and transfusion-associated transmission - United States, 2003. MMWR Morb Mortal Wkly Rep 2004;53:281-284.

38 U.S. Department of Health and Human Services, Food and Drug Administration, Center for Biologics Evaluation and Research: Guidance for Industry: Assessing Donor Suitability and Blood Product Safety in Cases of Known or Suspected West Nile Virus Infection. 2005. www.fda.gov/BiologicsBloodVaccines/GuidanceCompliance RegulatoryInformation/Guidances/Blood/ucm074111. htm (last accessed April 21, 2016)

39 de Oliveira AM, Beecham BD, Montgomery SP, Lanciotti RS, Linnen JM, Giachetti C, Pietrelli LA, Stramer SL, Safranek TJ: West Nile virus blood transfusion-related infection despite nucleic acid testing. Transfusion 2004;44:1695-1699.

40 Busch MP, Wright DJ, Custer B, Tobler LH, Stramer SL, Kleinman SH, Prince HE, Bianco C, Foster G, Petersen LR, Nemo G, Glynn SA: West Nile virus infections projected from blood donor screening data, United States, 2003. Emerg Infect Dis 2006;12:395-402.
41 Tsai TF, Popovici F, Cernercu C, Campbell GL, Nedelcu NI: West Nile encephalitis epidemic in south-eastern Romania. Lancet 1998;352:767-771.

42 European Centre for Disease Prevention and Control Review of the epidemiological situation of West Nile virus infection in the European Union. Update September 19, 2011. http://ecdc.europa.eu/en/publications/ Publications/110920_TER_Rapid\%20risk\%20assessment_ WNF.pdf (last accessed April 21, 2016).

43 Berger SA: West Nile Fever: Global Status, 2012. Los Angeles, Gideon e-books, 2012. Available at. $w w w$. gideononline.com/ebooks/disease/west-nile-fever-globalstatus/.

44 Commission Directive 2004/33/EC of March 22, 2004 implementing Directive 2002/98/EC of the European Parliament and of the Council as regards certain technical requirements for blood and blood components. 30.03.2004: L91:25-39.

45 Commission Directive 2002/98/EC of the European Parliament and of the Council of January 27, 2003. Setting standards of quality and safety for the collection, testing, processing, storage and distribution of human blood and blood components and amending Directive 2001/83/EC. 08.02.2003: L33:30-40.

46 Commission Decision 2007/875/EC amending Decision No 2119/98/EC of the European Parliament and of the Council and Decision 2000/96/EC as regards communicable diseases listed in those decisions. 28.12.2007: L344:48-49.

47 Commission Decision 2008/426/EC amending Decision 2002/253/EC laying down case definitions for reporting communicable diseases to the Community network under Decision $\mathrm{N}^{\circ}$ 2119/98/EC of the European Parliament and of the Council. 18.06.2008: L159:46-90.

48 European Commission Decision 2009/312/EC. Amending Decision 2000/96/EC as regards dedicated surveillance networks for communicable diseases 03.04.2009: L91:27-30.

49 Zeller HG, Schuffenecker I: :West Nile virus: an overview of its spread in Europe and the Mediterranean Basin in contrast to its spread in the Americas. Eur J Clin Microbiol Infect Dis 2004;23:147-156.

50 Paul-Ehrlich-Institut: Bekanntmachung über die $\mathrm{Zu}$ lassung von Arzneimitteln - Abwehr von Arzneimittelrisiken Stufe II - Änderung des Bescheides über die Anordnung des Ausschlusses von Blutspendern zur Verhinderung einer möglichen Übertragung des WestNil-Virus durch nicht pathogen-inaktivierte Blutkomponenten. Bundesanzeiger 07.03.2014 B6.

51 Dreier J, Vollmer T, Hinse D, Heuser EJ, Pisani G, Knabbe C: Implementation of NAT Screening for West Nile virus and experience with seasonal testing in Germany. Transfus Med Hemother 2016;43:28-36.

52 Pai A, Kleinman S, Malhotra K, Lee-Haynes L, Pietrelli L, Saldanha J: Performance characteristics of the Food and Drug Administration-licensed Roche Cobas TaqScreen West Nile virus assay. Transfusion 2008;48: 2184-2189.

53 Linnen JM, Deras ML, Cline J, Wu W, Broulik AS, Cory RE, Knight JL, Cass MM, Collins CS, Giachetti C: Performance evaluation of the Procleix West Nile virus assay on semi-automated and automated aystems. J Med Virol 2007;79:1422-1430.

54 Baylis SA, Chudy M, Nübling CM: Standardization of NAT for blood-borne pathogens. Transfus Med Hemother 2015;42:211-218.

55 Saldanha J, Shead S, Heath A, Drebot M; West Nile Virus Collaborative Study Group: Collaborative study to evaluate a working reagent for West Nile virus RNA detection by nucleic acid testing. Transfusion 2005;45: 97-102. 
56 Dodd RY, Foster GA and Stramer SL: Keeping blood transfusion safe from West Nile virus: American Red Cross experience, 2003 to 2012. Transfusion Med Rev 2015;29:153-161.

57 Pupella S, Pisani G, Cristiano K, Catalano L, Grazzini G: Update on West Nile virus in Italy. Blood Transfus 2014;12:626-627.

58 Commission Directive 2014/110/EU amending Directive 2004/33/EC as regards temporary deferral criteria for donors of allogeneic blood donations. Official Journal of the European Union. 17.12.2014: L 366:81-82.

59 European Directive 2005/62/EC 'implementing Directive 2002/98/EC of the European Parliament and of the Council as regards Community standards and specifications relating to a quality system for blood establishments'. Official Journal of the European Union. 30.09.2005: L256:41-48.
60 Pisani G, Pupella S, Marino F, Gaggioli A, Sambri V, Rossini G, Wirz M, Grazzini G: Interlaboratory study to evaluate the performance of laboratories involved in West Nile virus RNA screening of blood and blood components by nucleic acid amplification testing in Italy. Blood Transfus 2011;9:425-429.

61 Pisani G, Pupella S, Cristiano K, Marino F, Simeoni M, Luciani F, Scuderi G, Sambri V, Rossini G, Gaibani P, Pierro A, Wirz M, Grazzini G: Detection of West Nile virus RNA (lineages 1 and 2) in an external quality assessment programme for laboratories screening blood and blood components for WNV by NAT. Blood Transfus 2012;0:515-520.

62 Pupella S, Pisani G, Cristiano K, Catalano L, Grazzini G: West Nile virus in the transfusion setting with a special focus on Italian preventive measures adopted in 2008-2012 and their impact on blood safety. Blood Transfus 2013;11:563-574.
63 Napoli C, Iannetti S, Rizzo C, Bella A, Di Sabatino D, Bruno R, Sauro F, Martini V, Santucci VU, Declich S, Calistri P: Vector borne infections in Italy: results of the integrated surveillance system for West Nile disease in 2013. Biomed Res Int 2015;2015:643439.

64 Bellini R, Calzolari M, Mattivi A, Tamba M, Angelini P, Bonilauri P, Albieri A, Cagarelli R, Carrieri M, Dottori M, Finarelli AC, Gaibani P, Landini MP, Natalini S, Pascarelli N, Rossini G, Velati C, Vocale C, Bedeschi $\mathrm{E}$ : The experience of West Nile virus integrated surveillance system in the Emilia-Romagna region: five years of implementation, Italy, 2009 to 2013. Euro Surveill 2014;19:pii: 20953. 